\section{Horticultural Education Association Year Book}

Ir is with great pleasure that we notice the appearance of a Year Book of the Horticultural Education Association for 1932 (South-Eastern Agricultural College, Wye. 3s. 6d. post free). This volume, which we hope is the first of a long series, contains many items of importance to members of the Association, but also has several articles of general horticultural importance. Horticultural activities in various counties are described by the respective county agents or supervisors. Other articles refer to spray spreaders, vegetable breeding, glasshouse research, vegetable diseases, insecticides and fruit storage problems. The Association and particularly the editor, Mr. R. T. Pearl, are to be congratulated upon the production of a very useful volume at a reasonable price.

\section{Marmite}

WE have received from the Marmite Food Extract Co., Ltd., London, E.C.3, a booklet describing the medieinal and dietetic value of 'Marmite'. This is an extract of yeast, rich in vitamins $B_{1}$ and $B_{2}$. Vitamin B helps maintain the appetite and proper function of the digestive tract, and also aids growth, reproduction, and lactation. The reserves in the body are very small, so that a regular daily intake is required. Recent work has shown that 'Marmite' is of value in the treatment of the pernicious anæmia of pregnancy, in the anæmia of sprue and cœliac disease and possibly also in true Addisonian pernicious anæmia : all these anæmias belong to the megalocytic group. Strauss and Castle believe that normal hæmatopoiesis depends upon the interaction of two factors, an intrinsic one present in normal gastric juice, and an extrinsic one occurring in certain foodstuffs, which is abundant in 'Marmite' and may be identical with vitamin $B_{2}$. Up to 4 ounces of 'Marmite' may be taken daily by an adult.

\section{Dorothy Temple Cross Research Fellowships in Tuberculosis}

The Dorothy Temple Cross research fellowships in tuberculosis for the academic year 1933-1934 will shortly be awarded by the Medical Research Council, and applications should be lodged with the Council not later than June 1. The object of these fellowships is to give special opportunities for study and research to persons "intending to devote themselves to the advancement by teaching or research of curative or preventive treatment of tuberculosis in all or any of its forms". Candidates must be British subjects and must possess suitable medical, veterinary or scientific qualifications. The fellowships will preferably be awarded for projected studies or inquiries outside Great Britain. They will be awarded for one year as a rule, and are of the annual value of not less than £350. It may also be possible to award a senior fellowship of considerably greater value for an intensive study of some partieular problem of tuberculosis at a chosen centre in another country. Further particulars are obtainable from the Secretary, Medical Research Council, 38, Old Queen Street, Westminster, S.W.1.

\section{Announcements}

THE Daniel-Pidgeon fund for 1933 of the Geological Society of London has been awarded to Mr. J. D. Solomon, who proposes to undertake the correlation of the Pleistocene deposits of south-eastern England with those of neighbouring parts of the Continent.

Senatore Prince Ginori Conti will read a paper on "The Natural Springs of Tuscany and their Industrial Application" before the Royal Society of Arts, Adelphi, London, on May 3, at 8 p.m. The historical development of the venture and its condition at the present day will be described, and illustrated by a film. The natural steam power developments, with special reference to boracic acid production, at Larderello, Tuscany, were described in an article in NATURE of January 14, 1928.

THE annual meeting of the members of the Royal Institution for the election of officers and to receive the annual report of the Visitors for the year 1932, will be held on May 1. At the conclusion of the annual meeting a portrait of Sir William Bragg, painted by Mr. William Nicholson, will be presented to the Royal Institution.

The Ministry of Health has issued revised port sanitary regulations (Statutory Rules and Orders, 1933, No. 38) which will come into operation on May 1, together with an explanatory circular (1296). These regulations will replace several regulations of 1907,1920 , and 1929. The aim is to consolidate most of the regulations relating to the control of shipping in ports, and to bring quarantine procedure into line with modern methods of international interchange of information relating to epidemic diseases.

Applicatrons are invited for the following appointments, on or before the dates mentioned:-An assistant borough electrical engineer for the Fulham Borough Council-The Town Clerk, Town Hall, Fulham, S.W.6 (May 8). A professor of mathematics and natural philosophy at the McCrea Magee College, Londonderry-The Secretary of the Faculty (May 10). A headmaster of the Ashton-under-Lyne Junior Technical School-G. W. Handforth, Education Office, 8, Warrington Street, Ashton-underLyne (May 13). An independent lecturer in mathe. matical physics at the Queen's University of BelfastThe Secretary (June 12). A woman teacher of science, agricultural science, gardening, geography, and hygiene at the Shortwood Training College for Women Elementary Teachers, Constant Spring, P.O., Jamaica-The Secretary, Cross Roads P.O., Jamaica. A mechanical draughtsman for the Sudan Railways -The Controller, Sudan Government London Office, Wellington House, Buckingham Gate, S.W.1. Mechanical engineers in the Royal Army Ordnance Corps-The Under-Secretary of State (A.G.9), The War Office, S.W.1.

Erratum. In Nature of April 22, p. 565, col. 2, lines 15 and 16, for phrase "one asymmetric carbon atom" read "no asymmetric carbon atom". 